Chirurgia (2019) 114: 579-585

No. 5, September - October

Copyright $@$ Celsius

http://dx.doi.org/10.21614/chirurgia.114.5.579

\title{
The Tubercle of Zuckerkandl is Associated with Increased Rates of Transient Postoperative Hypocalcemia and Recurrent Laryngeal Nerve Palsy After Total Thyroidectomy
}

\author{
Cosmin Giulea, Octavian Enciu, Elena Adelina Toma, Valentin Calu, Adrian Miron
}

Department of Surgery, Elias University Emergency Hospital, Bucharest, Romania

Corresponding author:

Octavian Enciu, MD

Elias University Emergency Hospital

Blvd. Mărăsti nr. 17, Sector 1

Bucharest, Romania

E-mail: esoctavian@gmail.com

Received: 29.08 .2019

Accepted: 05.10.2019

\section{Rezumat}

Tuberculul Zuckerkandl este asociat cu rate crescute de hipocalcemie postoperatorie tranzitorie și pareză de nerv laringeu recurent după tiroidectomie totală

Conceptul actual de rezecție completă a parenchimului tiroidian a modificat atitudinea chirurgicală de la tiroidectomie subtotală la tiroidectomie totală pentru o gamă largă de afecțiuni tiroidiene benigne şi maligne şi a readus în discuție tuberculul Zuckerkandl. Acest rest embriologic a fost descris în repetate rânduri ca având o relație constantă cu nervul laringeu recurent şi glandele paratiroide superioare şi poate fi utilizat ca punct de repet pentru o disecție sigură. Pentru a evalua impactul prezenței tuberculului Zuckerkandl asupra celor mai importante complicații ale chirurgiei tiroidiene, am studiat prospectiv 128 pacienți diagnosticați cu boli tiroidiene benigne care au necesitat tiroidectomie totală. Absența tuberculului Zuckerkandl sau tubercul grad 0 conform Pelizzo et al a fost observată în 42 cazuri (32.8\%). Intraoperator au fost identificați 38 tuberculi grad 1 (29.7\%), 31 tuberculi grad $2(24.2 \%)$ şi 16 tuberculi grad $3(12.5 \%)$. Din totalul de 11 tuberculi identificați bilateral, 4 au fost gradul 3. Dintre cei 47 pacienți cu tuberculi gradul 2 şi $3,18(38.3 \%)$ au prezentat hipocalcemie postoperatorie tranzitorie $(\mathrm{p}<0.0001, \mathrm{r}=0.47)$ şi $10(21.3 \%)$ pareză temporară de nerv laringeu recurent $(\mathrm{p}=0.004, \mathrm{r}=0.25)$. Toți pacientii au recuperat deficitele pe parcursul urmăririi postoperatorii. Tubercului Zuckerkandl, atunci când este prezent şi de dimensiuni semnificative, este asociat cu rate crescute ale hipocalcemiei postoperatorii şi parezei recurențiale temporare. 
Cuvinte cheie: tubercul Zuckerkandl, tiroidectomie totală, hipocalcemie postoperatorie, pareză de nerv laringeu recurent

\section{Abstract}

The current concept of complete resection of thyroid parenchyma shifted the practice from subtotal thyroidectomy to total thyroidectomy for a wide range of benign and malignant thyroid affliction and brought the tubercle of Zuckerkandl once again into attention. This embryological remnant has been shown to have a constant relationship with the recurrent laryngeal nerve and the superior parathyroid gland and may be used as a landmark for safe dissection. In order to assess if the presence of the tubercle of Zukerkandl has an impact on the most important complications of thyroid surgery, we have prospectively studied 128 patients diagnosed with nodular goiter who underwent total thyroidectomy. Grade 0 or the absence of the tubercle of Zuckerkandl, according to Pellizo et al, was noted in 42 cases (32.8\%). During surgery, we identified 38 grade 1 tubercles (29.7\%), 31 grade 2 tubercles (24.2\%) and 16 grade 3 tubercles (12.5\%). Out of 11 bilateral tubercles, 4 were measured as grade 3. Of all 47 patients with grade 2 and 3 tubercles, $18(38.3 \%)$ developed transient postoperative hypocalcemia $(\mathrm{p}<0.0001, \mathrm{r}=0.47)$ and $10(21.3 \%)$ transient postoperative nerve palsy $(\mathrm{p}=0.004, \mathrm{r}=0.25)$. All patients fully recovered during follow-up. The tubercle of Zuckerkandl, when present and of significant macroscopic size is associated with increased rates of transient postoperative hypocalcemia and recurrent laryngeal nerve palsy.

Key words: tubercle of Zuckekandl, total thyroidectomy, postoperative hypocalcemia, recurrent laryngeal nerve palsy

\section{Introduction}

Thyroid afflictions have seen a rise in prevalence and incidence during the past decades, with an almost 3 -fold increase in the past three decades, mainly due to the increase in access to high-resolution ultrasonography across the economic spectrum of countries (1). While not all thyroid nodules may require surgical treatment or even fine needle aspiration biopsy, this surge in diagnosis has inevitably led to an increase in the number of total, near-total and subtotal thyroidectomies, as well as lobectomies for both malignant and benign diseases of the thyroid (2). This has also been linked to changes in lifestyle, though correlations between dietary preferences, smoking and alcohol intake and endocrine abnormalities are still under debate $(3,4)$. Nevertheless, an epidemiological study conducted in the United States analysing data from 1996-2006 found that the total number of thyroidectomies has increased almost 40\% during that time frame, with a definite upturn in outpatient procedures (5).

Despite this increase in number, total thyroidectomy is still a very safe procedure with very sparse permanent postoperative complications, especially regarding recurrent laryngeal nerve palsy and hypoparathyroidism (6). Notwithstanding, due to the high variability of local anatomy and the different dissection techniques employed by surgeons, temporary dysphonia may occur in up to $11 \%$ of cases, while transient hypocalcemia may be encountered in as many as $30 \%$ of patients (7). Permanent hypoparathyroidism has been reported in up to $2 \%$ of cases, while permanent recurrent larygneal nerve palsy has been reported with extremely high variability, between as low as $1 \%$ and as high as $11 \%(6,8,9)$. 
Current efforts are aimed at finding a standardized technique that can help reduce these complications to the lowest possible values. Even though it used to be a subject of intense debate and seemingly endless controversy, it has been established that clear identification of the recurrent laryngeal nerve (with or without intraoperative nerve monitoring) and parathyroid glands should always be performed during surgery $(9,10)$. Routine identification of the recurrent laryngeal nerve should be performed after the gland has been mobilized, with the exception of cases where the tubercle of Zuckerkandl and the ligament of Berry are encountered. The distal portion of the recurrent laryngeal nerve can often be covered by the tubercle of Zuckerkandl, which is why the nerve may be at risk when dissection is performed in this area (11). While the presence and size of the tubercle of Zuckerkandl have been inconstantly reported to correlate with preoperative symptoms, it has been reported that in the overwhelming majority of cases, it helped locate the recurrent laryngeal nerve which usually resides medially to an enlarged tubercle (more often visible on the right side) and using this anatomic landmark improved postoperative morbidity (12-14).

Zuckerkandl's tubercle represents a posterior and lateral projection of the thyroid lobe and is present in $60-90 \%$ of adults. An embryological remnant formed by the fusion of the ultimobranchial body and the median thyroid process, the tubercle is usually found in the area of the cricothyroid junction and can be observed more frequently on the right side. $(13,15)$. The superior parathyroid glands are likely to reside cranially to the inferior thyroid trunk in the superficial layer of the vascular fascia, upwards and posteriorly to the tubercle. The tubercle must be resected with the specimen when performing total thyroidectomy to prevent disease recurrence and has been mentioned repeatedly as a landmark in both recurrent laryngeal nerve and superior parathyroid gland identification (15-18). Maria Rosa Pelizzo et al. have emphasized the relation of the tubercle with the recurrent laryngeal nerve and have proposed a classification according to the tuberculum size (19).

\section{Material and Method}

A prospective, observational study was designed to evaluate the rates of postoperative hypocalcemia and recurrent laryngeal nerve palsy when confronted during dissection with a significant tubercle of Zuckerkandl. All patients diagnosed with benign thyroid disease undergoing total thyroidectomy during January - December 2015 were enrolled. Patient data were recorded in a prospective manner, and none required additional dissection steps (i.e. central neck dissection). Patients with recorded preoperative hypocalcemia (total calcium $<8 \mathrm{mg} / \mathrm{dL}$, ionic calcium $<2 \mathrm{mEq} / \mathrm{L}$ ) were excluded. ENT evaluation before surgery was indicated only for patients with voice alterations. Of 143 patients with benign disease that underwent total thyroidectomy, 14 had preoperative hypocalcemia and one patient and right vocal cord dysfunction of uncertain causes, thusly 128 patients were enrolled in the study. All patients underwent total thyroidectomy standard capsular dissection technique with routine identification of the recurrent laryngeal nerve.

The presence or absence of the tubercle was noted during surgery and measurements were taken immediately after resection of the surgical specimen (Fig. 1). A surgical calliper was used to measure the height of the tubercle from the level of the posterior surface of the gland in order to grade the tubercles according to Pellizo (19).

Postoperatively, calcemia was evaluated in the first and second postoperative day (at discharge), and at 30 and 60 days follow-up. Hypocalcemia was considered a record of total calcium of less than $8 \mathrm{mg} / \mathrm{dL}$ and ionic calcium of less than $2 \mathrm{mEg} / \mathrm{L}$. All patients with hypocalcemia received Vitamin D and Calcium supplements at discharge.

Patients with voice alterations underwent ENT evaluation in the second postoperative day and were followed-up weekly in the first month 


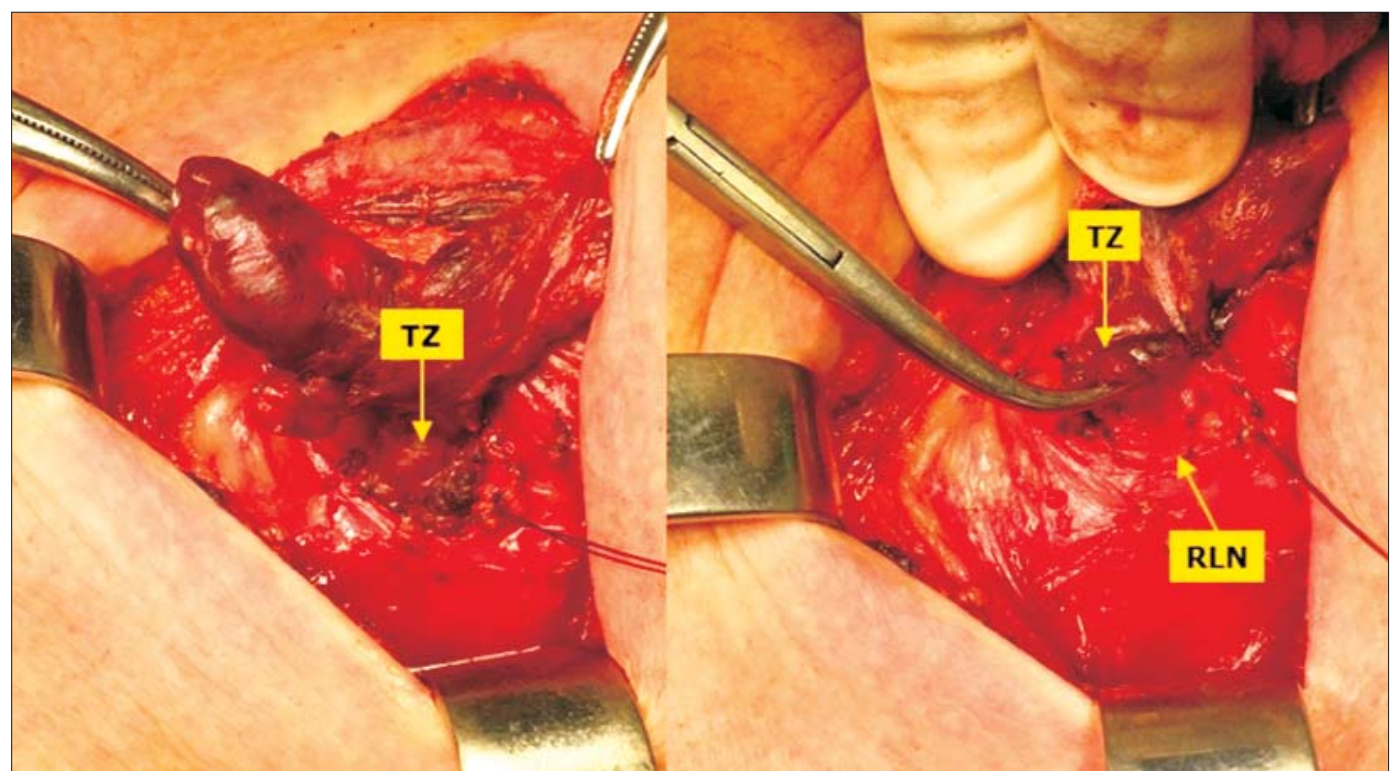

Figure 1. Identification of the tubercle of Zuckerkandl (TZ) - grade 2 and the recurrent laryngeal nerve (RLN)

after surgery and monthly for the next 6 months or until full recovery was documented.

A complete database was developed in Microsoft Excel ${ }^{\circledR}$ and add-ins like WinStat and XLstat were used to perform Pearson's (r) and Spearman's (rho) test to certify correlations.

General features of the enrolled patients are listed in Table 1.

\section{Results}

The mean age of the studied patients was 50.66 years (range 15-76 years). More than

Table 1. General features of studied patients

\begin{tabular}{lll}
\hline Median Age (years) & & $50.66(15-76)$ \\
\hline Gender & Men & $22(17.18 \%)$ \\
& Women & $106(82.81 \%)$ \\
\hline Goiter Grading (WH0) & Grade 0 & $2(1.56 \%)$ \\
& Grade 1 & $47(36.17 \%)$ \\
& Grade 2 & $51(39.84 \%)$ \\
Intervention & Grade 3 & $28(21.87 \%)$ \\
\hline Zuckerkandl Tubercle & Total Thyroidectomy & $128(100 \%)$ \\
& Absent & $42(32.8 \%)$ \\
Pathology Report & Present & $86(67.2 \%)$ \\
& Hyperplasia & $89(69.53 \%)$ \\
& Adenoma & $21(16.40 \%)$ \\
& Graves's Disease & $5(3.9 \%)$ \\
& Tiroiditis & $13(10.15 \%)$ \\
\hline
\end{tabular}

$80 \%$ were female patients. The vast majority of the patients had grade 1 and grade 2 goiters according to the WHO goiter grading, only $21.87 \%$ having grade 3 goiter. The final pathology reports confirmed that all patients had beingn disease.

Grade 0 or the absence of the tubercle of Zuckerkandl, according to Pellizo et al, was noted in 42 cases (32.8\%). During surgery, we identified 38 grade 1 tubercles (29.7\%), 32 grade 2 tubercles (25.0\%) and 16 grade 3 tubercles (12.5\%). Of 11 bilateral tubercles, 4 were measured as grade 3. (Fig. 2) Overall, 81 patients had grade 0 and 1 tubercles and the remaining 47 patients had significant, macroscopic, grade 2 and 3 tubercles. In all cases studied, the recurrent laryngeal nerve travelled medial and posterior to the tubercle (Fig. 3).

Postoperative hypocalcemia (Table 2) was found in 20 cases $(15.6 \%$ of all studied patients) and it was significantly associated with grade 2 tubercles - 13 patients $(65 \%)$ and grade 3 tubercles -5 patients $(25 \%)(\mathrm{p}<0.0001$, rho $=$ 0.40 ). Of all 47 patients with high grade (grade 2 and 3) tubercles, 18 (38.3\%) developed postoperative hypocalcemia $(\mathrm{p}<0.0001, \mathrm{r}=0.47)$. None of studied patients developed permanent hypoparathyroidism, but required supplementation and calcium and vitamin D during 


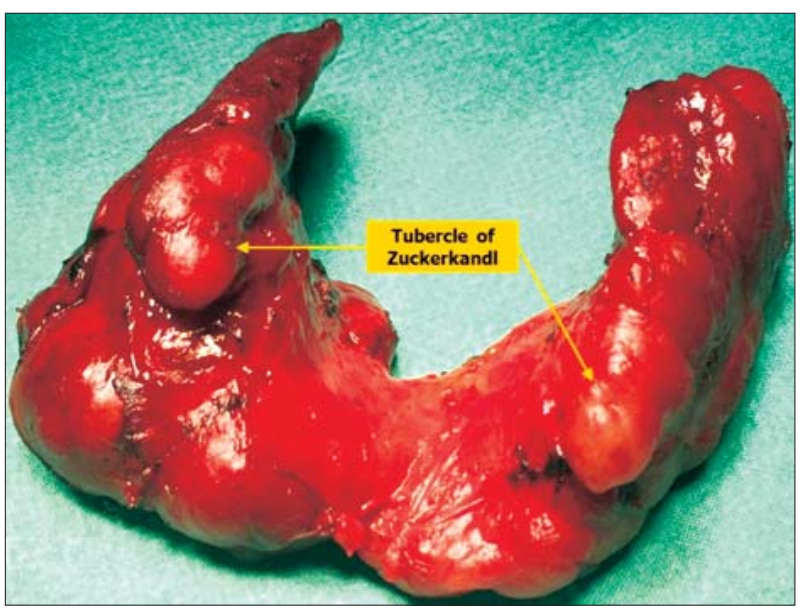

Figure 2. Bilateral Grade 3 Tubercle of Zuckerkandl

follow-up until normal serum calcium levels were restored.

Recurrent laryngeal nerve palsy documented by ENT examination in the second postoperative day was noted in 14 patients (10.93\%). During ENT examination, unilateral altered mobility of vocal cords was found in 3 patients with grade 1 tubercles (31.4\%), 6 patients with grade 2 tubercles $(42.8 \%)$ and in 4 patients $(28.5 \%)(\mathrm{p}=0.004, \mathrm{rho}=0.25)$. Overall, 10 patients $(21.2 \%)$ with high grade (grade 2 and 3 ) tubercles had postoperative nerve palsy $(p=0.004, r=0.25)$. None of the patients had permanent nerve injury (Table 3).

\section{Discussion}

Total thyroidectomy remains the best option for the immediate and permanent cure of

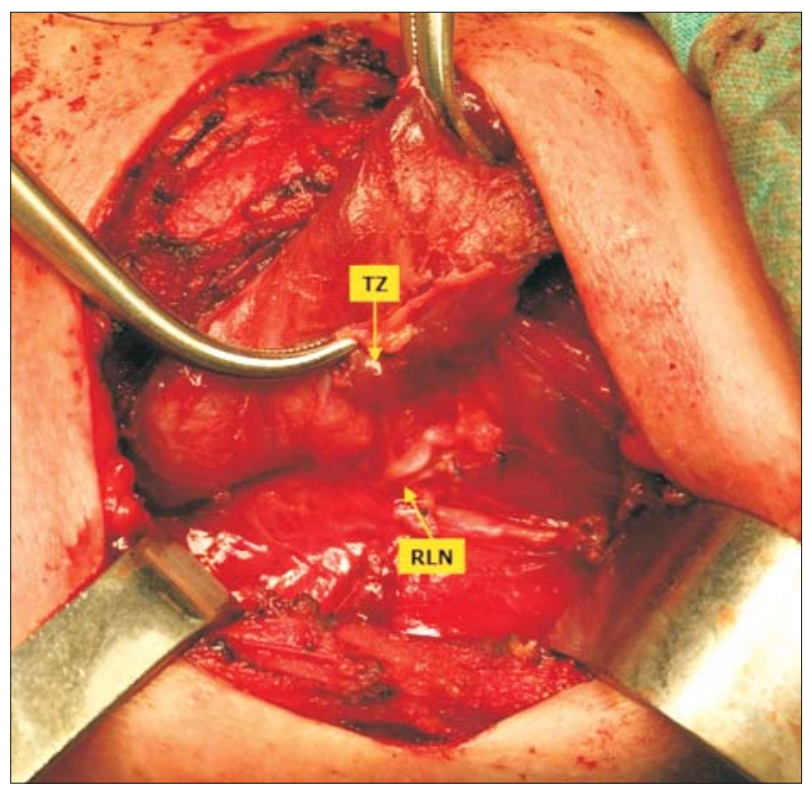

Figure 3. Grade 2 tubercle of Zuckerkandl and the recurrent laryngeal nerve (RLN)

multinodular goitre and Graves' disease and the obvious indication for thyroid cancer $(20,21)$. Even with the relative safety of thyroidectomies in experienced hands, with the rise in procedures performed worldwide came a rise in reported postoperative complications and the focus has swiftly changed towards careful dissection techniques and more accurate identification of relevant structures at risk $(5,22-24)$.

Complete resection of thyroid parenchyma even for benign disease led to a shift from subtotal thyroidectomy to total thyroidectomy and the rediscovery of the tubercle of

Table 2. Postoperative Hypocalcemia

\begin{tabular}{|c|c|c|c|c|}
\hline \multicolumn{2}{|c|}{ Total Number of Patients $=128$} & \multicolumn{2}{|c|}{ Postoperative Calcemia } & \multirow[t]{2}{*}{$\mathrm{p}(\mathrm{r} / \mathrm{rho})$} \\
\hline & & $\begin{array}{c}\text { Hypocalcemia } \\
\text { (20 patients) }\end{array}$ & $\begin{array}{l}\text { Normal values } \\
\text { (108 Patients) }\end{array}$ & \\
\hline Goiter Grading (WHO) & $\begin{array}{l}\text { Grade } 0 \\
\text { Grade 1 } \\
\text { Grade } 2 \\
\text { Grade } 3\end{array}$ & $\begin{array}{c}0(0 \%) \\
5(25 \%) \\
10(50 \%) \\
5(25 \%)\end{array}$ & $\begin{array}{c}2(1.8 \%) \\
42(38.8 \%) \\
41(37.9 \%) \\
23(21.3 \%)\end{array}$ & $0.26($ rho $=0.10)$ \\
\hline Zuckerkandl Tubercle & $\begin{array}{l}\text { Grad } 0 \\
\text { Grad 1 } \\
\text { Grad } 2 \\
\text { Grad } 3\end{array}$ & $\begin{array}{c}0(0 \%) \\
2(10 \%) \\
13(65 \%) \\
5(25 \%)\end{array}$ & $\begin{array}{l}42(38.8 \%) \\
37(34.2 \%) \\
15(13.8 \%) \\
14(12.9 \%)\end{array}$ & $<0.0001($ rho $=0.40)$ \\
\hline $\begin{array}{l}81 \text { patients } \\
47 \text { patients }\end{array}$ & $\begin{array}{l}\text { Grade 0-1 } \\
\text { Grade 2-3 }\end{array}$ & $\begin{array}{c}2(2.4 \%) \\
18(38.3 \%)\end{array}$ & $\begin{array}{l}79(97.5 \%) \\
29(61.7 \%)\end{array}$ & $<0.0001(r=0.47)$ \\
\hline
\end{tabular}


Table 3. Postoperative Recurrent Laryngeal Nerve Palsy

\begin{tabular}{lcccc}
\hline \multicolumn{1}{l}{ Total Number of Patients } & $\mathbf{1 2 8}$ & \multicolumn{2}{c}{ Recurrent Laryngeal Nerve Palsy } & $\mathbf{p ~ ( r / r h o ) ~}$ \\
\hline & & $\begin{array}{c}\text { Yes } \\
\text { (14 patients) }\end{array}$ & $\begin{array}{c}\text { No } \\
\text { (114 Patients) }\end{array}$ & \\
\hline Goiter Grading (WHO) & Grade 0 & $0(0 \%)$ & $2(1.75 \%)$ & $0.62($ rho=0.04) \\
& Grade 1 & $5(35.7 \%)$ & $42(36.8 \%)$ & \\
& Grade 2 & $5(35.7 \%)$ & $46(40.3 \%)$ & \\
Zuckerkandl Tubercle & Grade 3 & $4(28.5 \%)$ & $24(21 \%)$ & $0.004($ rho=0.25) \\
& Grad 0 & $1(7.1 \%)$ & $41(35.9 \%)$ & \\
& Grad 1 & $3(31.4 \%)$ & $36(31.5 \%)$ & \\
& Grad 2 & $6(42.8 \%)$ & $22(19.2 \%)$ & \\
\hline 81 patients & Grad 3 & $4(28.5 \%)$ & $15(13.1 \%)$ & $0.004(\mathrm{r}=0.25)$ \\
47 patients & Grade 0-1 & $4(4.9 \%)$ & $77(95 \%)$ & \\
\hline
\end{tabular}

Zuckerkandl and its relationship with the recurrent laryngeal nerve and superior parathyroid gland. $(20,24)$ The dissection manoeuvres required to extract this deeply posterior projection of the thyroid gland may damage the structures in its close vicinity. Recurrent laryngeal nerve lesions are usually the result of traction or compression in its most vulnerable area, in the last $1-2 \mathrm{~cm}$ of extralaryngeal course, where it settles in the trachea-esophageal groove, but at the same time remains strongly attached to the ligaments of Berry and less than $1 \mathrm{~mm}$ away from glandular tissue - a complicated setting even without any local anatomical variations (18). The vessels supplying the parathyroid gland are extremely fragile and ample dissection around the tubercle of Zuckerkandl might jeopardize their integrity or lead to elongation and thrombosis.

Several observational studies, both of surgical anatomy and cadaveric dissection have reported that in the vast majority of cases, the recurrent laryngeal nerve lies posterior and medial to a grade 2 or 3 tubercle (25). While using the tubercle as a landmark for identification of the recurrent laryngeal nerve, nerves located laterally or anteriorly are at risk (12).

Using the grading system proposed by Pelizzo et al, we found that the standard description could benefit from a more palpable distinction between grades. Grade 0 and 1 , from an unrecognizable entity to a mere thickening of the posterior thyroid capsule have little relevance landmarks during dissection for safe thyroidectomy $(26,27)$.

Our findings indicate that only macroscopic consistent and large tubercles have clinical significance -18 patients out of 47 with grade 2 and 3 tubercles developed transient postoperative hypocalcemia and 10 patients developed temporary recurrent laryngeal nerve palsy. All patients had confirmed normal vocal cord function at 6 months and there was no case of permanent hypoparathyroidism.

Although we did not employ nerve monitoring, nor methylene blue staining for parathyroid identification, our overall results transient hypocalcemia (15.6\%) and temporary dysphonia due to laryngeal nerve palsy (10.9\%) are comparable with published data $(9,28)$.

The current study inadvertently has some limitations. Although the correlation between large tubercles and transient postoperative hypocalcemia and recurrent laryngeal nerve palsy is statistically significant, we can only assume that more dissection manoeuvres needed in the area of the nerve or parathyroid glands can lead to nerve injury (elongation) and impairment of parathyroid blood supply. Thyroiditis and long-standing large grade 3 goiters may demand similar ample dissection.

\section{Conclusion}

The tubercle of Zuckerkandl, when present and of significant macroscopic size - grade 2 
and 3 according to Pelizzo is associated with increased rates of transient postoperative hypocalcemia and recurrent laryngeal nerve palsy. This can be explained by more dissection manoeuvres in the vicinity of the recurrent laryngeal nerve and superior parathyroid gland.

\section{Conflict of Interest}

The authors declare no conflicts of interests.

\section{References}

1. Cronan JJJR. Thyroid nodules: is it time to turn off the US machines? 2008:247(3):602-4.

2. Gandolfi PP, Frisina A, Raffa MJABMAP. The incidence of thyroid carcinoma in multinodular goiter: retrospective analysis. 2004; 75(2):114-7.

3. Ericsson UB, Lindgärde FJJoim. Effects of cigarette smoking on thyroid function and the prevalence of goitre, thyrotoxicosis and autoimmune thyroiditis. 1991;229(1):67-71.

4. Brito JP, Yarur AJ, Prokop LJ, Mclver B, Murad MH, Montori VMJT. Prevalence of thyroid cancer in multinodular goiter versus single nodule: a systematic review and meta-analysis. 2013;23(4): 449-55.

5. Sun GH, DeMonner S, Davis MMJT. Epidemiological and economic trends in inpatient and outpatient thyroidectomy in the United States, 1996-2006. 2013;23(6):727-33.

6. Thomusch O, Machens A, Sekulla C, Ukkat J, Lippert H, Gastinger I, et al. Multivariate analysis of risk factors for postoperative complications in benign goiter surgery: prospective multicenter study in Germany. 2000;24(11):1335-41.

7. Christou N, Mathonnet MJJovs. Complications after total thyroidectomy. 2013;150(4):249-56

8. Ritter K, Elfenbein D, Schneider DF, Chen H, Sippel RSJjosr. Hypoparathyroidism after total thyroidectomy: incidence and resolution. 2015;197(2):348-53.

9. Dralle H, Sekulla C, Lorenz K, Brauckhoff M, Machens A, surgery GISGJWjo. Intraoperative monitoring of the recurrent laryngeal nerve in thyroid surgery. 2008;32(7):1358-66.

10. Jatzko GR, Lisborg PH, Müller M, Wette VMJS. Recurrent nerve palsy after thyroid operations--principal nerve identification and a literature review. 1994;115(2):139-44.

11. Reeve T, Thompson NWJWjos. Complications of thyroid surgery: how to avoid them, how to manage them, and observations on their possible effect on the whole patient. 2000;24(8):971-5.
12. Sheahan P, Murphy MSJTL. Thyroid tubercle of Zuckerkandl: importance in thyroid surgery. 2011;121(11):2335-7.

13. Gauger PG, Delbridge LW, Thompson NW, Crummer P, Reeve TSJEJoS. Incidence and importance of the tubercle of Zuckerkandl in thyroid surgery. 2001;167(4):249-54.

14. Hisham A, Aina E. Zuckerkandl's tubercle of the thyroid gland in association with pressure symptoms: a coincidence or consequence? Australian and New Zealand Journal of Surgery. 2000;70(4):251-3.

15. Abd-Elwahab E-SM, El-hady HA. Outcomes of total thyroidectomy with vs. without extensive intended dissection of the thyroid embryological remnants single centre experience. 2019.

16. Gauger PG, Delbridge LW, Thompson NW, Crummer P, Reeve TS. Incidence and importance of the tubercle of Zuckerkandl in thyroid surgery. European Journal of Surgery. 2001;167(4):249-54.

17. Page C, Cuvelier P, Biet A, Boute P, Laude M, Strunski VJTJoL, et al. Thyroid tubercle of Zuckerkandl: anatomical and surgical experience from 79 thyroidectomies. 2009;123(7):768-71.

18. Serpell JWJAoSO. New operative surgical concept of two fascial layers enveloping the recurrent laryngeal nerve. 2010;17(6): 1628-36.

19. Pelizzo MR, Toniato A, Gemo GJJotACoS. Zuckerkandl's tuberculum: an arrow pointing to the recurrent laryngeal nerve (constant anatomical landmark). 1998;187(3):333-6.

20. Wilhelm SM, McHenry CRJWjos. Total thyroidectomy is superior to subtotal thyroidectomy for management of Graves' disease in the United States. 2010;34(6):1261-4.

21. Barczyński M, Konturek A, Hubalewska-Dydejczyk A, Gołkowski F, Nowak WJWjos. Ten-year follow-up of a randomized clinical trial of total thyroidectomy versus Dunhill operation versus bilateral subtotal thyroidectomy for multinodular non-toxic goiter. 2018; 42(2):384-92.

22. Khadra M, Delbridge L, Reeve T, Poole A, Crummer PJA, Surgery NZJo. Total thyroidectomy: its role in the management of thyroid disease. 1992;62(2):91-5.

23. Efremidou El, Papageorgiou MS, Liratzopoulos N, Manolas KJJCJoS. The efficacy and safety of total thyroidectomy in the management of benign thyroid disease: a review of 932 cases. 2009;52(1):39.

24. Liu Q, Djuricin G, Prinz RAJS. Total thyroidectomy for benign thyroid disease. 1998;123(1):2-7.

25. Yalçin B, Poyrazo lu Y, Ozan HJST. Relationship between Zuckerkandl's tubercle and the inferior laryngeal nerve including the laryngeal branches. 2007;37(2):109-13.

26. Irkorucu OJAoM, Surgery. Zuckerkandl tubercle in thyroid surgery: Is it a reality or a myth? 2016;7:92-6.

27. Mirilas PJSt. Grades of Zuckerkandl's tubercle in normal thyroids. 2007;37(10):918-.

28. Farghaly A-EA-E, Ahmed MT, Kotb MB, Ibrahim IAJJoCMR, Practice. Conventional surgical techniques versus intraoperative methylene blue spraying for safe total thyroidectomy. 2019; $4(1): 67$. 